\title{
Framing The Poor: Media Illiteracy, Stereotyping, and Contextual Fallacy To Spin The Crisis
}

\author{
Christian Garland
}

\author{
christiangarland@hotmail.com
}

\begin{abstract}
The title of this contribution is a play-on-words: the media's deliberate stereotypical framing of the poorest section of society, many of whom are claimants of one kind or another, as being the internal social "other"- "not like us", but also literally attributing—usually indirectly—substantial blame for the ongoing crisis of capitalism to this same group, since it requires very minimal social entitlements for material survival and does not apparently create value. The media framing of this "common sense" simplified account of complex social problems is subject of this article. Whilst media manipulation of a passive and inert readership and/or audience has plenty of critics, this work contends that a Marxist understanding that also uses aspects of Chomsky's original propaganda model, provides the best resources available for making sense of the mass media's disingenuous framing and spin of social and political issues such as this in the contemporary UK.
\end{abstract}

Acknowledgement: This paper was presented as talk in the CAMRI (Communication and Media Research Institute) seminar at the University of Westminster, $22^{\text {nd }}$ October 2014.

The current and ongoing coalition government's policy of "welfare reform" can be seen in pretty stark terms for what it is: a war on the poor, however not it would seem by a substantial section of the electorate, who seem more or less to believe the media narrative of "lazyfeckless-workshy-scroungers", that is propagated on a loop, and fed into by the DWP press office-not to say politicians themselves.

Indeed, since at least the 1980s-not without significance for being the decade in which neoliberalism truly emerged onto the world-stage-the mantra of "welfare reform" has been a key tenet of policy for parties of all shades, but the incumbent Conservative-led UK coalition's project is quite seriously much more, and also deeply, and very pointedly ideological.

Such an ideological project unsurprisingly makes implicit use of Goebbels' original maxim for propaganda, "If you tell a lie big enough and keep repeating it, people will eventually come to believe it" ${ }^{\prime \prime}$, and a media narrative confected from a populist imaginary itself both cause and effect of the said media narrative, propagates and endlessly repeats in print on terrestrial TV, and radio, social myths that bear little if any resemblance to social reality. Early last year, the results of a TUC survey on "Misconceptions on Welfare" were released, where on average the survey sample believed $41 \%$ of the social security budget is spent on unemployment benefits, in spite of the actual percentage being $3 \%$. Similarly, survey respondents believed $27 \%$ of the same budget is claimed fraudulently, as opposed to the actual figure of $0.7 \%$, while the same sample of respondents believed $48 \%$ of social security spending went on Job Seeker's Allowance, rather than the actual figure of $27.8 \%$ (Grice 2013).

The myths embodied in the vastly inaccurate perceptions of the sample survey quoted, do indeed find their origin besides in quotidian, and first person word-of-mouth gossip, in such cynical sound bite as Chancellor George Osborne claiming his and the coalition's war on the poor, is in support of "the shiftworker, leaving home in the dark hours of the early morning,

\footnotetext{
${ }^{1}$ Quotes "If you tell a lie big enough and keep repeating it, people will eventually come to believe it" and "The bigger the lie, the more it will be believed" are widely and incorrectly attributed to Goebbels. It is probable that these are the paraphrases of the Goebbels' text "Churchill's Lie Factory" where he said: "The English follow the principle that when one lies, one should lie big, and stick to it. They keep up their lies, even at the risk of looking ridiculous."-Joseph Goebbels, "Aus Churchills Lügenfabrik," January 12, 1941, Die Zeit Ohne Beispiel Joseph Goebbels (Maćašev 2005).
} 
who looks up at the closed blinds of their next-door neighbour sleeping off a life on benefits" (Osborne quoted in Grice 2013). No less apparent in the media propaganda war the DWP and incumbent coalition are engaged in, are the throwaway terms used by David Cameron as much as his policy-hacks, and churned out by spin doctor Lynton Crosby, "workers and shirkers" (Cameron PMQs quoted in Douieb 2012), "strivers and skivers", and of course the favoured post-political swing demographic originally popularised by Gordon Brown, "hard working families". Such a 'Steady Diet of Nothing' to borrow from two other well-known sources, ${ }^{2}$ manufactures consent (Herman and Chomsky 1988) toward what in every sense, is the diametric opposite of being in the interests of those believing and repeating it: in this case, a right-wing administration hell bent on dismantling an already very minimal welfare state at any cost, a very minimal welfare state that is meant to offer minimal social entitlements to anyone experiencing unemployment, for example as a likely possibility at some point for very many, if not the majority of the readers of The Sun, or Daily Mail ${ }^{3}$, a part of the "maybe eighty percent of the population whose main function is to follow orders and not think, and not to pay attention to anything who usually pay the costs" (Chomsky 1992).

Similar to Chomsky's own "eighty percent" more than 20 years ago, applied to media ideology and the specific example of the (mis)representation of the reality of unemployment, a sweated majority is divided and then sub-divided in turn, against each other, in order to provide tangible but bogus targets for frustration and anger, lest this target become those directly responsible for forcing it to live in conditions of worsening misery. It remains to be seen however, how long this can continue, as more and more of that same divided and subdivided majority begin to "join-the-dots" and start holding the real architects of 'the crisis' responsible.

So far, the sickly content of media confections have been critically outlined, but it is important here to make critical sense of some of the examples of the stereotyping at work in their manufacture. Taking a preview article in the Mail on Sunday on Channel 4's notorious reality TV series, Benefits Street, filmed on a street in the deprived inner city Winson Green area of the city, the author, a Mail on Sunday reporter headlines the article, "From hard workers to shirkers: How Benefits Street was home to tradesman and working class labourers before culture of dependency set in" (2014), noting in the bye line, "Ninety per cent of residents living in the 137-house street claim benefits". The opening sentence declares "Viewers have been shocked by Channel 4's Benefits Street, portraying the lives of welfaredependent residents on a road in Birmingham", to be sure to confirm the existing ignorant prejudices of its readers, and for anyone approaching the subject for the first time, giving a thoroughly skewed selective presentation of one very particular example that is itself-being after all "reality TV"-a completely simulated construction of "reality". The article makes implicit use of another favourite of reality TV, "historical reality TV", which is of course ahistori$\mathrm{cal}$ nostalgic re-enactment of the past under the artificial conditions of being a television programme. It does this with visual props too, having black and white photos of the honest, striving manual worker residents of the 1910s, juxtaposed with colour photos of the fag-puffing, mobile-wielding claimant residents of 2014-as well as a picture of refuse including discarded mattresses, for maximum "abandon all hope..." effect. The piece also has a link to a Channel 4 promotional video, entitled, Take a look at Benefits Street ${ }^{4}$, and the actual series will be further looked at in the course of this text, but to return to the Mail on Sunday piece.

"According to census information, the terrace house now occupied by Deirdre "White Dee" Kelly was lived in by labourer James Jones, his wife and their five children, and his brotherin-law and sister-in-law", the article declares, making an erroneous comparison of the work-

\footnotetext{
2 "Steady Diet of Nothing" (Fugazi 1991). (Dischord), is also reportedly a quote from the late comedian and social commentator Bill Hicks, though cannot be verified.

${ }^{3}$ The Sun and Daily Mail remain the two most widely read tabloid "red top" titles in 2014, despite the decline in circulation for print media over the course of the last decade, and further since precipitated by digitization. ABCs: National daily newspaper circulation June 2014, quoted in The Guardian, June 11, 2014. http://www.theguardian.com/media/table/2014/jul/11/abcs-national-newspapers

${ }^{4}$ Take a Look at Benefits Street. Channel 4 promotional video, cited in Mail on Sunday 2014.
} 
ing class in the very early Twentieth-Century, with a section of it from the very early TwentyFirst, to supposedly contrast the two, when no such comparison can actually be made. Were the author of the piece to do some background work and examine the realities of life for the working class in 1910s Britain, they would find something certainly akin to what that section of it the media likes to portray in 2014 as "workless"-a term derived from the welfare-towork industry, and beloved by incumbent DWP minister, lain Duncan-Smith.

The "good honest" workers of the 1910s, would shortly be obliterated en masse of course, as cannon fodder in World War One, and continue to live impoverished and desperate lives for another fifteen or so years, until the Great Depression of the 30s would also render them en masse, unwanted surplus labour, something well-documented by George Orwell in The Road to Wigan Pier. The article however cites "Historian Bill Dargue", who is indirectly quoted as saying "many people in the street 100 years ago worked in the iron trade, which would have been "hard and physical," before adding, "In contrast, James Turner Street today is blighted with crime and unemployment. Residents include alcoholic James Clarke, known as Fungi, and Mark Thomas, who admitted fiddling his benefits" (Mail on Sunday 2014). Taking a stereotyped "human face" to claimants, is of course what the TV programme in question aims to do, and the preview tabloid article does similar, offering, unnamed, and uncited "Researchers" who "say the area used to be full of tradesmen and labourers as families moved in for work", not of course adding that the employed proletariat of 100 years ago had a continual struggle for survival and lived wholly according to whether or not its labour was required, dependent of course on the caprices of the market. This being the Mail on Sunday, a folksy "common sense" homily concludes, quoting "another nostalgic contributor", who says, "Those were the days when you didn't lock your door in the day unless the siren from the prison went off" (Mail on Sunday 2014)-the siren from the prison built to confine those members of the proletariat found to be straying from the narrowly mapped life-course of reproduction-factory-death, plotted for them by capital and state.

As will be clear from this paper, the mass media can certainly be said to serve entrenched interests of wealth and power, that is, of elites who wish to preserve the existing form of society-capitalism—at any cost. So in creating "an attractive environment for investors", that maxim of party politics the world over, competing post-political elites vying for the "nonpolitical" swing electorate vote which decides elections, can really do no better than find imagined targets for the said demographics' frustration and anger at its own apparent impotence and lack of power, and claimants, the unwanted surplus labour of capital, come very close to "immigrants" as the preferred target. Indeed, the contemporary British media is very close to Herman and Chomsky's original propaganda model, being owned and controlled after all by a few billionaire capitalists and their shareholders, such as Rupert Murdoch and News Corp, and Viscount Rothermere and Daily Mail and General Trust Plc, who remain the "major agenda-setting media" (Herman and Chomsky 1988).

They're the ones who own the media and they're the ones who have to be in a position to make the decisions. They have an overwhelmingly dominant role in the way life happens. You know, what's done in the society. Within the economic system, by law and in principle, they dominate. The control over resources and the need to satisfy their interests imposes very sharp constraints on the political system and on the ideological system (Herman and Chomsky 1988).

This extensive quotation from Chomsky answering questions on his famous book a few years later, is not meant to be taken as a word-for-word application to the UK in 2014, and as is well-known, the "media-setting agenda" referred to is much more advertisers than readers or viewers, but does also refer to the overarching power the media exert on helping to set and circumscribe the terms of acceptability, both within the media discourse itself, and indeed politics.

Coming back to the "media illiteracy" mentioned in the title of this paper, it can be understood as the actual situation of passivity and inertia that is the position of the reader, viewer, and listener in the contemporary context, meaning what is read, viewed, or heard in the me- 
dia is "how-it-is", and of course a "factual" account of the world and events taking place in it. Such media illiteracy can also be seen in a feedback loop with the two other concepts mentioned in the title, stereotyping, and contextual fallacy. Put very simply, the day-to-day environment of capitalist society is the foremost and "primary factor" here ill-equipping a majority of its members for seeing or making sense of it, or their own situation. Anecdotal "first person" stereotyping is tapped into by journalists, television and radio producers, who in turn make cynical use of it as a crucial ingredient in the ideological product consumed by readers, viewers and listeners, who in turn have what they believe further confirmed by that same media consumption. Taking as a further example Channel 4's now-notorious line in "poverty porn", which goes back at least five or so years-so a timeline starting roughly from the early years of the global crisis of capitalism, ongoing and far into its sixth year-there was the 2012 "special investigation" of an episode of the channel's 'cutting edge documentary' series, Dispatches, entitled Tricks of the Dole Cheats. As was said in an email at the time and sent to Channel 4 the next day,

The programme's title was also extremely misleading, since the expected 'tricks' of 'dole cheats'-seriously, was that copy and pasted from The Sun online and slightly revised to avoid copyright breaches? - were not forthcoming at all. It would have been contemptible enough if this had been another straightforward attack on the unemployed and other claimants, but the programme still had much to offer in that regard, even though the title was completely different from the implied content.

Morland Sanders, the presenter, who in the best tradition of those who speak from where they don't know-or have any idea-took the miserable reality of claiming JSA, and the requirement that claimants record what they have 'been doing' to find employment every two weeks when signing on, as 'getting away with it'. As someone who has had that distinctly tepid pleasure in the past on two separate occasions, I can speak from experience, and tell you that were a claimant not to undertake this (yes, largely pointless) fortnightly task, they would have their JSA frozen forthwith. To quote and counter Morland Sanders here, a JSA claimant can most certainly not '[...] write on their jobseeker's agreement, "I'm not going to apply for this job, and I'd rather stay on benefits'". So, to answer Morland Sanders' speculative assertion, 'It does make me think, that if you wanted to actively avoid work and stay on benefits, you could.' No, you couldn't. (Garland 2012)

The unfortunate and purposely misleading message of the cited Dispatches episode and other television outlets for demonizing claimants, is that existing stereotyped perceptions "are true", and "here is the proof", the media and viewer feedback loop in play. Channel 4 which as anyone knows, has long since moved far away from its origins can make use of its original mandate to provide "challenging" material, by airing anything at all regardless of how little it bares any resemblance to the channel's original purpose, and of course, lowest-commondenominator tabloid fare such as Benefit Busters (2009), The Fairy Job Mother (2011), Secrets of the Dole Cheats (2012) and Benefits Street (2013), can be fallaciously claimed to be fulfilling the original purpose of the channel. What is observable at work in such cynical bad faith, can also be observed in operation in the exact wording of the existing DWP legislation that JSA claimants can face 'sanction' meaning removal of JSA for "refusing the help that is offered", just as the more punitive the already punitive benefits system becomes, compulsion is referred to as being "help" that is "offered", and anything at all undertaken by the punitive benefits system is referred to as "support", since freely using the indefinite article and abstract nouns, any and all activity by the state can be called that, even though it is openly its exact opposite. Such use of language in the wording of legislation in which ultimately the unemployed claimant has no choice in at all, is deliberately made for the one-sided 'interpretation' by the Job Centre and welfare-to-work industry (DWP and Hoban 2012), to mean whatever they choose, but the choice for the claimant amounting to what it always was you don't have one.

We began with critically analysing the terms of media coverage of unemployment and benefit claimants, and indeed as has been further elaborated, the hand in glove relation that 
exists between politics and the output of that media to "frame the poor" as an internal social 'other' unlike the majority. Contextual fallacy is made extensive use of in doing so, as the preferred mode of presenting what can be considered "facts" in a decontexualized vacuum rendering them utterly meaningless, but more importantly what was formerly factual information taken out of its original context, can be used to 'explain' whatever the propagandist wants, whether it is the DWP Press Office, the Secretary of State for Work and Pensions, or the Daily Mail and it has the same desired effect, feeding back into the same loop of passivity and inertia of the electorate.

Concluding this text, another and very recent example of the DWP's disingenuous ongoing contribution to spinning the crisis can be highlighted. Indeed, as any statistical scrutinizing shows, unemployment never falls quarter-on-quarter, by any more than 20,000-40,000 but the DWP Press Office (DWP and McVey 2014) - as for all other coalition and media sources, proudly declared last week that "Unemployment fell below 2 million" in the quarter, so by 150,000 , or year-on-year by a ludicrous 538,000 . When are examined the actual "facts" involved in such starry-eyed twaddle, the criteria for defining the "record fall", betray the very explicitly ideological purpose to which they are put.

The DWP, of course using technical pedantry as its get out clause, is careful not to word anything as being other than there being "over half a million fewer unemployed people than there were a year ago", the fact that the statistical goalposts are moved continuously as do the ONS's, and such a record-breaking fall is thanks to simply reclassifying vast numbers of JSA claimants as newly "self-employed", and thus removing them from the unemployment total, can never be made explicit, and never is, any more than can the raw facts of former JSA claimants usually being worse off than when they were signing on, getting $£ 50$ a week in tax credits, and whatever they can make selling catalogues door-to-door or doing some other form of individualized and insecure piece work, or the fact that all those still registered as claimants but compelled onto some variant of workfare or under "sanction" are omitted too., it can be added in relation to the subject under discussion here that such a message really is illustrated well by quotation from Chomsky, "That's the whole point of good propaganda. Nobody knows what it means, because it doesn't mean anything. You want to create a slogan that nobody's going to be against, and everybody's going to be for" (Chomsky 1997). And herein there is the media "framing the poor" as one if not a major 'cause' of the crisis in the British economy, and the need to "pay off the deficit" as an explanation for continuous savage cuts themselves merely one part of ongoing state efforts to shore up the crisis of global capitalism.

\section{References}

Chomsky, Noam. 1992. Excerpts from Manufacturing Consent: Noam Chomsky and the Media. http://www.chomsky.info/interviews/1992----02.htm

Chomsky, Noam. 1997. Media Control: The Spectacular Achievements of Propaganda. New York: Seven Stories Press.

DWP and Esther McVey. 2014. Largest Fall in Unemployment Since Records Began. Press Release. Gov.uk. Accessed January 11, 2015. https://www.gov.uk/government/news/largest-fall-inunemployment-since-records-began.

DWP and Mark Hoban. 2012. Choosing a Live on Benefits is No Longer an Option. Press Release. Gov.uk. https://www.gov.uk/government/news/choosing-a-life-on-benefits-is-no-longer-an-option.

Douieb, Tiernan. 2012. Workers and Shirkers. Huffington Post UK, The Blog. http://www.huffingtonpost.co.uk/tiernan-douieb/workers-and-shirkers_b_1664564.html.

Fuchs, Christian. 2013. How Ideology is Policing the Crisis of European Capitalism. Christian Fuchs: Information, Society, Technology \& Media. Blog. Accessed January 11, 2015. http://fuchs.uti.at/tag/ideology-is-policing-the-crisis-of-european-capitalism/.

Garland, Christian. 2012. Combat Channel 4's 'Tricks of the Dole Cheats'. Relative Autonomy: Media, Film \& Politics. Accessed January 11, 2015. http://www.relativeautonomy.com/blog/combatchannel-4s-tricks-of-the-dole-cheats.

Grice, Andrew. 2013. Voters 'brainwashed by Tory welfare myths', shows new poll. The Independent. Accessed January 11, 2015. http://www.independent.co.uk/news/uk/politics/voters-brainwashedby-tory-welfare-myths-shows-new-poll-8437872.html. 
Herman, Edward S. and Noam Chomsky. 1988. Manufacturing Consent: The Political Economy of the Mass Media. New York: Pantheon.

Maćašev, Aleksandar. 2005. Joseph Goebbels. http://www.goebbels.info/goebbels-goebbels.htm.

Mail on Sunday. 2014. From hard workers to shirkers: How Benefits Street was home to tradesman and working class labourers before culture of dependency set in. Mail on Sunday. http://www.dailymail.co.uk/news/article-2541759/From-hard-workers-shirkers-How-Benefits-Streethome-tradesman-working-class-labourers-culture-dependency-set-in.html.

The Guardian. 2014. ABCs: National Daily Newspaper Circulation June 2014. The Guardian. http://www.theguardian.com/media/table/2014/jul/11/abcs-national-newspapers.

\section{About the Author}

\section{Christian Garland}

writes and publishes-broadly speaking -in the tradition of Critical Theory, the Frankfurt School kind, but has interests beyond that, including protest and social movements informed by autonomist Marxism and anarchism. Having the degrees BA Philosophy and Politics (UEA), and MA Social and Political Thought (Sussex), he will return to a PhD in September 2015, subject to funding. He has taught at the Universities of Edinburgh formerly ECAWarwick, Bedfordshire, and most recently, at Middlesex. 